\title{
Detection of Helicobacter pylori DNA in the saliva of patients complaining of halitosis
}

\begin{abstract}
Correspondence
Nao Suzuki

naojsz@college.fdcnet.ac.jp
\end{abstract}

Received 21 May 2008

Accepted 5 August 2008

\author{
Nao Suzuki, Masahiro Yoneda, Toru Naito, Tomoyuki Iwamoto, \\ Yousuke Masuo, Kazuhiko Yamada, Kazuhiro Hisama, Ichizo Okada \\ and Takao Hirofuji
}

Section of General Dentistry, Department of General Dentistry, Fukuoka Dental College, 2-15-1, Tamura, Sawara-ku, Fukuoka 814-0193, Japan

\begin{abstract}
Helicobacter pylori infection, which causes peptic ulcers and gastric cancer, is considered a possible cause of halitosis. Recently, the oral cavity was identified as a possible $H$. pylori reservoir, particularly in the presence of periodontal disease, which is a cause of halitosis. The purpose of this study was to evaluate by PCR the prevalence of oral $H$. pylori in the saliva of subjects complaining of halitosis. Samples were obtained from 326 non-dyspeptic subjects, comprising 251 subjects with actual malodour and 75 subjects without halitosis. DNA was extracted from the samples, and the presence of $H$. pylori and periodontopathic bacteria including Porphyromonas gingivalis, Treponema denticola and Prevotella intermedia was examined by PCR. H. pylori was detected in $21(6.4 \%)$ of 326 samples. The methyl mercaptan concentration and periodontal parameters including tooth mobility, periodontal pocket depth (PPD) and occult blood in the saliva were significantly greater in the $H$. pylori-positive subjects. Each of the periodontopathic bacteria was also detected at a significantly higher frequency in the $H$. pylori-positive subjects. Among those patients with a PPD of $\geqslant 5 \mathrm{~mm}$ and a tongue coating score of $\leqslant 2$, no difference was observed in oral malodour levels between the $H$. pylori-positive and -negative subjects. However, the presence of occult blood in the saliva and the prevalence of Prevotella intermedia were significantly greater in the $H$. pylori-positive subjects. $H$. pylori was detected in $16(15.7 \%)$ of 102 subjects with periodontitis, suggesting that progression of periodontal pocket and inflammation may favour colonization by this species and that $H$. pylori infection may be indirectly associated with oral pathological halitosis following periodontitis.
\end{abstract}

\section{INTRODUCTION}

Helicobacter pylori is a spiral, microaerophilic, Gramnegative bacterium that colonizes the human gastrointestinal tract, primarily the stomach (Covacci et al., 1999). It is also believed to be responsible for gastritis and peptic ulcers, and is a risk factor for gastric cancer (Dunn et al., 1992; Parsonnet et al., 1991; Warren \& Marshall, 1983); however, the mode of transmission of $H$. pylori is poorly understood. Several studies have detected $H$. pylori in the human oral cavity, particularly in patients with gingivitis or chronic periodontitis (Anand et al., 2006; Gebara et al., 2006; Souto \& Colombo, 2008), and have thus suggested that the oral cavity is the primary extragastric reservoir for $H$. pylori. In contrast, other studies have failed to find evidence supporting the role of the oral cavity as a major reservoir of $H$. pylori (Czesnikiewicz-Guzik et al., 2004; Loster et al., 2006).

Abbreviations: OLT, organoleptic test; PPD, periodontal pocket depth; VSC, volatile sulfur compound.
Halitosis is a common problem in humans, and oral malodour is largely caused by periodontitis, tongue debris, poor oral hygiene, deep caries, inadequately fitted restorations and endodontic lesions (Rosenberg et al., 1991; Tonzetich, 1977; Yoneda et al., 2006); specifically, it is primarily the result of the microbial metabolism of amino acids in local debris (Scully et al., 1994). Many of the compounds that contribute to oral malodour are volatile sulfur compounds (VSCs) such as hydrogen sulfide $\left(\mathrm{H}_{2} \mathrm{~S}\right)$, methyl mercaptan $\left(\mathrm{CH}_{3} \mathrm{SH}\right)$ and dimethyl sulfide $\left(\mathrm{CH}_{3} \mathrm{SCH}_{3}\right)$ (Kleinberg \& Westbay, 1990; Tonzetich, 1977). Periodontopathic bacteria, including Porphyromonas gingivalis, Treponema denticola, Prevotella intermedia and Fusobacterium nucleatum, produce $\mathrm{H}_{2} \mathrm{~S}$ and $\mathrm{CH}_{3} \mathrm{SH}$ (Fukamachi et al., 2005; Tonzetich \& McBride, 1981). Additionally, methylamine, dimethylamine, propionic acid, butyric acid, indole, scatole and cadaverine have been reported to cause oral malodour (Goldberg et al., 1994; Kostelc et al., 1981). To evaluate the level of oral malodour in patients complaining of halitosis, clinicians typically measure their VSC level and give them an organoleptic test (OLT) (Lee et al., 2007). 
To diagnose halitosis, a simple classification with corresponding treatment needs has been developed (Miyazaki et al., 1999; Yaegaki \& Coil, 2000), which includes the categories of genuine halitosis, pseudo-halitosis and halitophobia. Genuine halitosis is subclassified as physiological or pathological halitosis, and pathological halitosis is subclassified as oral or non-oral pathological halitosis. Physiological halitosis is caused largely by poor oral hygiene and tongue debris, whereas oral pathological halitosis is caused largely by periodontal disease (Yaegaki \& Sanada, 1992). Non-oral pathological halitosis can originate from the upper respiratory tract and from other sources that are carried by blood and exhaled in the lung (Delanghe et al., 1997; Tangerman \&Winkel, 2007). Gastrointestinal diseases are also generally believed to cause halitosis (Adler et al., 2005; Tydd \& Dyer, 1974). In this study, oral $H$. pylori DNA was detected in the saliva of subjects complaining of halitosis and the relationships between oral $H$. pylori infection and oral health and malodour were examined.

\section{METHODS}

Study population. Three hundred and twenty-six subjects (137 males and 189 females with a mean age \pm SD of $45.3 \pm 15.0$ years) complaining of halitosis and presenting to the Oral Malodour Clinic at Fukuoka Dental College Medical and Dental Hospital, Japan, between June 2005 and February 2008 were recruited for the study. Informed consent was obtained from all enrolled individuals, none of whom had taken antibiotics within 3 months prior to the study. All of the subjects were non-dyspeptic. Prior to the appointment for malodour assessment, each subject was asked to refrain from eating, drinking, chewing, brushing or rinsing the mouth for at least $5 \mathrm{~h}$. On the basis of the VSC data, 251 subjects were determined to have actual malodour (total VSCs $\geqslant 0.25$ p.p.m.), while 75 subjects had almost no malodour beyond socially acceptable levels (total VSCs $<0.25$ p.p.m.).

Malodour assessment. The severity of malodour in each individual was determined using an OLT and gas chromatography (model GC14B; Shimadzu Works). For the OLT, each patient was instructed to exhale through the mouth with moderate force into a Teflon sampling bag (GL Science) for 2-3 s to prevent dilution of the mouth odour with lung and room air. This procedure was repeated until approximately 1 litre of air was obtained. Two or three evaluators then estimated the odour at a distance of approximately $10 \mathrm{~cm}$ from the sampling bag. The OLT scores ranged from 0 to 5 ( 0 , absence of odour; 1 , questionable odour; 2 , slight malodour; 3 , moderate malodour; 4 , strong malodour; 5 , severe malodour) (Miyazaki et al., 1999) and the mean values of the scores assigned by the three judges were recorded. For the gas chromatographic measurements, the subjects were asked to remain quiet with a closed mouth for $30 \mathrm{~s}$, after which mouth air $(10 \mathrm{ml})$ was aspirated with a gas-tight syringe. Subsequently, the samples were injected onto a gas chromatograph column at $70{ }^{\circ} \mathrm{C}$. A glass column was packed with $25 \% \beta, \beta$ 9-oxydipropionitrile on a 60-80 mesh Chromosorb W AWDMCS-ST device (Shimadzu Works) fitted with a flame photometric detector. The concentration of each VSC was determined based on the values for standard $\mathrm{H}_{2} \mathrm{~S}, \mathrm{CH}_{3} \mathrm{SH}$ and $\mathrm{CH}_{3} \mathrm{SCH}_{3}$ gas prepared with a PD-1B permeater (GL Science). The threshold levels for genuine halitosis were defined as an OLT score of $\geqslant 3, \geqslant 0.15$ p.p.m. $\mathrm{H}_{2} \mathrm{~S}$ in the mouth air, $\geqslant 0.05$ p.p.m. $\mathrm{CH}_{3} \mathrm{SH}$ in the mouth air, $\geqslant 0.02$ p.p.m. $\mathrm{CH}_{3} \mathrm{SCH}_{3}$ in the mouth air and $\geqslant 0.25$ p.p.m. total VSCs (Tonzetich \& Ng, 1976; Yaegaki \& Coil, 2000).
Clinical examinations. The oral health of each patient was evaluated based on the number of teeth, number of caries, number of fillings, no-good margin, mobility of the teeth, periodontal pocket depth (PPD), degree of tongue coating, volume of stimulated salivary flow and the presence of occult blood in the saliva. PPD was measured at six points around each tooth in all of the subjects. Each subject's periodontal status was determined based on the presence of teeth with a PPD of $\geqslant 5 \mathrm{~mm}$. The total area and thickness of the tongue coating were determined by clinical inspection with a simple modification (Oho et al., 2001; Suzuki et al., 2008). The degree of tongue coating was assessed based on conventional criteria, with a simple modification ( 0 , no tongue coating; 1 , thin tongue coating covering less than one-third of the tongue dorsum; 2, thick tongue coating covering approximately one-third of the tongue dorsum or thin tongue coating covering one-third to two-thirds of the tongue dorsum; 3 , thick tongue coating covering one-third to two-thirds of the tongue dorsum or thin tongue coating covering more than twothirds of the tongue dorsum; and 4, thick tongue coating covering more than two-thirds of the tongue dorsum) (Oho et al., 2001). Tongue-coating scores of $\geqslant 3$ were considered to be a cause of oral malodour. The volume of stimulated salivary flow was measured using the chewing gum test. Each patient was asked to pool saliva in the oral cavity then spit into a vessel every minute throughout the entire collection period ( $5 \mathrm{~min}$ ). Testing for the presence of occult blood in the saliva was performed using a Perioscreen (Sunstar).

Conventional PCR assays. The prevalence of $H$. pylori and major periodontal bacteria, including Porphyromonas gingivalis, Treponema denticola and Prevotella intermedia, in the saliva of the subjects was determined by PCR. The sequences of oligonucleotide primers used in this study are listed in Table 1. The chromosomal DNA of the bacteria in the saliva was prepared by physical rupture using a Disruptor Genie cell disrupter (Scientific Industries) with zirconium and tungsten carbide beads. Briefly, $500 \mu \mathrm{l}$ stimulated whole saliva and an equal amount of PBS were mixed and centrifuged at $12000 \mathrm{~g}$ for $10 \mathrm{~min}$. Subsequently, $300 \mu \mathrm{l}$ lysis buffer $(50 \mathrm{mM}$ Tris/ $\mathrm{HCl}$, $\mathrm{pH} 8.0 ; 1 \mathrm{mM}$ EDTA; and $1 \%$ SDS), $0.3 \mathrm{~g}$ zirconium beads and a tungsten carbide bead ( $3 \mathrm{~mm}$ diameter) were added to the precipitate, which was then boiled at $100{ }^{\circ} \mathrm{C}$ for $10 \mathrm{~min}$. The oral bacteria in the saliva samples were ruptured using a cell disrupter at room temperature for $3 \mathrm{~min}$. The DNA was then purified by repeated phenol/chloroform extraction, precipitated with $100 \%$ ethanol and resuspended in $100 \mu \mathrm{l}$ TE $(10 \mathrm{mM}$ Tris/ $\mathrm{HCl}, \mathrm{pH} 8.0$; and $1 \mathrm{mM}$ EDTA). Each $10 \mu \mathrm{l}$ volume of the PCR mixture contained $0.25 \mathrm{mM}$ deoxynucleotide triphosphates, $10 \mathrm{mM}$ Tris/ $\mathrm{HCl}(\mathrm{pH} 8.3), 50 \mathrm{mM}$ $\mathrm{KCl}, 2 \mathrm{mM} \mathrm{MgCl}_{2}, 5 \mathrm{U}$ Taq polymerase, $2 \mu \mathrm{M}$ each primer and $2 \mu \mathrm{l}$ template DNA. Amplification was conducted using a TaKaRa PCR thermal cycler with the following temperature profile: $94{ }^{\circ} \mathrm{C}$ for $2 \mathrm{~min}$, followed by 30 cycles of $94{ }^{\circ} \mathrm{C}$ for $10 \mathrm{~s}, 55^{\circ} \mathrm{C}$ for $15 \mathrm{~s}$ and $72{ }^{\circ} \mathrm{C}$ for $1 \mathrm{~min}$, with a final extension at $72{ }^{\circ} \mathrm{C}$ for $5 \mathrm{~min}$. The amplified products were loaded onto $1.5 \%(\mathrm{w} / \mathrm{v})$ agarose gels, separated by electrophoresis, stained with ethidium bromide $(0.5 \mu \mathrm{g}$ $\mathrm{ml}^{-1}$ ) and photographed under UV light.

Specificity of the PCR assay. The specificity of the PCR assay was tested against chromosomal DNA from 18 oral bacteria: Streptococcus mutans Xc, Streptococcus sobrinus 6715, Streptococcus mitis 903, Streptococcus oralis ATCC 10557, Streptococcus sanguinis ATCC 10556, Streptococcus gordonii DL1, Streptococcus pneumoniae WU2, Actinomyces naeslundii ATCC 51655, Actinomyces viscosus ATCC 43146, Eikenella corrodens 1085, Haemophilus aphrophilus NCTC 5908, Aggregatibacter actinomycetemcomitans Y4, Porphyromonas gingivalis ATCC 33277 and W83, F. nucleatum ATCC 10953, Tannerella forsythensis ATCC 43037, Prevotella intermedia ATCC 25611 and Treponema denticola ATCC 35405. Chromosomal DNA from $H$. pylori ATCC 43504 was used as a positive control. The PCR 
Table 1. Species-specific primers for PCR used in this study

\begin{tabular}{|c|c|c|c|}
\hline Species & Primer sequence $\left(5^{\prime} \rightarrow 3^{\prime}\right)^{\star}$ & Product size (bp) & Reference \\
\hline H. pylori & $\begin{array}{l}\text { F: CTATGACGGGTATCCGGC } \\
\text { R: ATTCCACCTACCTCTCCCA }\end{array}$ & 375 & Nyan et al. (2004) \\
\hline Porphyromonas gingivalis & $\begin{array}{l}\text { F: TGTAGATGACTGATGGTGAAAACC } \\
\text { R: ACGTCATCCCCACCTTCCTC }\end{array}$ & 211 & Yoshida et al. (2003) \\
\hline Treponema denticola & $\begin{array}{l}\text { F: TAATACCGAATGTGCTCATTTACAT } \\
\text { R: TCAAAGAAGCATTCCСTCTTCTTCTTA }\end{array}$ & 316 & Ashimoto et al. (1996) \\
\hline Prevotella intermedia & $\begin{array}{l}\text { F: TTTGTTGGGGAGTAAAGCGGG } \\
\text { R: TCAACATCTCTGTATCCTGCGT }\end{array}$ & 575 & Ashimoto et al. (1996) \\
\hline
\end{tabular}

${ }^{\star} \mathrm{F}$, Forward; R, reverse.

amplicons were further identified by RFLP analysis using enzymes MspI and TaqaI.

Statistical analysis. Statistical analysis of the differences in the frequency of malodour, clinical symptoms and periodontopathic bacteria between the $H$. pylori-positive and -negative specimens was performed using a $\chi^{2}$ test and an unpaired $t$-test. The SPSS statistical software package was used for all analyses (release $11.0 \mathrm{~J}$; SPSS Japan).

\section{RESULTS AND DISCUSSION}

\section{Specificity of the PCR assay}

A 375 bp PCR product was obtained with chromosomal DNA from a pure culture of $H$. pylori ATCC 43504. Similar patterns were obtained by digesting PCR amplicons from clinical samples and $H$. pylori ATCC 43504 using RFLP analysis (Fig. 1).

\section{Prevalence of oral $\boldsymbol{H}$. pylori in a Japanese population}

The demographic and clinical parameters of the subject group are shown in Table 2. Overall, H. pylori was detected in $21(6.4 \%)$ of 326 samples. The prevalence of oral $H$.

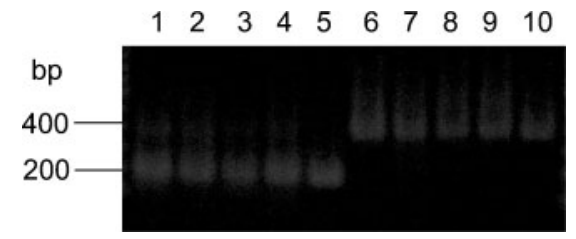

Fig. 1. PCR products of clinical specimens and chromosomal DNA of $H$. pylori ATCC 43504 analysed by RFLP analysis. Lanes 1 and $6, H$. pylori-positive saliva sample from patient no. 61 ; lanes 2 and $7, H$. pylori-positive saliva sample from patient no. 72; lanes 3 and $8, H$. pylori-positive saliva sample from patient no. 128 ; lanes 4 and $9, H$. pylori-positive saliva sample from patient no. 241 ; lanes 5 and 10, chromosomal DNA of $H$. pylori ATCC 43504. In lanes 1-5, the fragments were digested with $\mathrm{Mspl}$, whilst in lanes $6-10$, the fragments were digested with Taqal. pylori as determined by PCR in Japanese gastric patients was previously reported as 7 or $26 \%$ in saliva and $24 \%$ in dental plaque (Ishihara et al., 1997; Shimada et al., 1994). This is the first report of oral H. pylori in non-dyspeptic Japanese individuals. Cross-sectional studies have consistently shown a gradual increase in $H$. pylori seroprevalence with age, which has been interpreted as a birth cohort effect reflecting a decrease in the rate of acquisition in successive generations as sanitation and the standard of living have improved (Malaty et al., 2003; Parsonnet et al., 1992). The highest reported prevalence of oral $H$. pylori was observed in subjects between 30 and 39 years $(10.3 \%)$ and between 50 and 59 years in the present study (9.2\%). No significant difference was detected between the $H$. pylori-positive and -negative subjects according to age, sex, number of teeth, number of caries, number of fillings or stimulated salivary flow. Based on the results of serological tests to detect the presence of antibodies against $H$. pylori, the carriage rate of $H$. pylori is reported to be $20-80 \%$ for adults in the developed world and more than $90 \%$ in the developing world (Taylor \& Blaser, 1991). The prevalence of H. pylori in Japanese adults is reported to be $55 \%$ (Fujisawa et al., 1999). Souto \& Colombo (2008) detected H. pylori in the subgingival biofilm samples of $24 \%$ of the population without dyspepsia. Conversely, Olivier et al. (2006) did not detect $H$. pylori in dental samples from subjects with positive stomach biopsies. These findings indicate that the oral cavity may act as a reservoir for $H$. pylori, regardless of infection in the stomach.

\section{Prevalence of oral $\boldsymbol{H}$. pylori and oral malodour}

The $\mathrm{CH}_{3} \mathrm{SH}$ levels as measured by gas chromatography were significantly higher in the $H$. pylori-positive group than in the $H$. pylori-negative group; however, no significant difference was observed in the levels of $\mathrm{H}_{2} \mathrm{~S}$, $\mathrm{CH}_{3} \mathrm{SCH}_{3}$ and total VSCs, or in the OLT score (Table 3). $\mathrm{CH}_{3} \mathrm{SH}$ gas is thought to be elevated in patients with periodontal involvement (Yaegaki \& Sanada, 1992). Among the clinical symptoms associated with oral malodour, periodontal symptoms including tooth mobility, a PPD of $\geqslant 5 \mathrm{~mm}$, a PPD of $\geqslant 6 \mathrm{~mm}$ and occult blood 
Table 2. Demographic and clinical parameters for the $H$. pylori-positive and -negative subjects

\begin{tabular}{|lcc|}
\hline Parameter & H. pylori-positive $(\boldsymbol{n}=\mathbf{2 1})$ & H. pylori-negative $(\boldsymbol{n}=\mathbf{3 0 5})$ \\
\hline Age (years) & $43.8 \pm 12.1$ & $45.4 \pm 14.9$ \\
$10-19(\%)$ & $0.0(0 / 21)$ & $5.9(18 / 305)$ \\
$20-29(\%)$ & $9.5(2 / 21)$ & $11.1(34 / 305)$ \\
$30-39(\%)$ & $38.1(8 / 21)$ & $23.0(70 / 305)$ \\
$40-49(\%)$ & $9.5(2 / 21)$ & $20.3(62 / 305)$ \\
$50-59(\%)$ & $38.1(8 / 21)$ & $25.9(79 / 305)$ \\
$60-69(\%)$ & $4.8(1 / 21)$ & $17.0(52 / 305)$ \\
$\geqslant 70(\%)$ & $0.0(0 / 21)$ & $3.6(11 / 305)$ \\
Females (\%) & $47.6(10 / 21)$ & $58.7(179 / 305)$ \\
Males (\%) & $52.4(11 / 21)$ & $41.3(126 / 305)$ \\
Number of teeth & $26.7 \pm 2.7$ & $26.3 \pm 4.7$ \\
Number of caries & $0.5 \pm 1.2$ & $0.6 \pm 1.6$ \\
Number of fillings & $13.8 \pm 5.8$ & $12.5 \pm 5.7$ \\
Stimulated salivary flow $(\mathrm{ml}$ per 5 min) & $7.3 \pm 3.5$ & $6.7 \pm 6.3$ \\
\hline
\end{tabular}

Table 3. Oral malodour parameters in the H. pylori-positive and -negative subjects

\begin{tabular}{|c|c|c|c|c|}
\hline Parameter & & H. pylori-positive $(n=21)$ & H. pylori-negative $(n=305)$ & $P$ value \\
\hline \multicolumn{5}{|l|}{ Oral malodour level } \\
\hline \multirow[t]{2}{*}{$\mathrm{H}_{2} \mathrm{~S}$} & $\geqslant 0.15$ p.p.m. & $90.5(19 / 21)$ & $75.1(229 / 305)$ & NS \\
\hline & $<0.15$ p.p.m. & $9.5(2 / 21)$ & $24.9(76 / 305)$ & \\
\hline \multirow[t]{2}{*}{$\mathrm{CH}_{3} \mathrm{SH}$} & $\geqslant 0.50$ p.p.m. & $100(21 / 21)$ & $82.6(252 / 305)$ & $<0.05$ \\
\hline & $<0.50$ p.p.m. & $0(0 / 21)$ & $17.4(53 / 305)$ & \\
\hline \multirow[t]{2}{*}{$\left(\mathrm{CH}_{3}\right) \mathrm{S}$} & $\geqslant 0.02$ p.p.m. & $81(17 / 21)$ & $72.8(222 / 305)$ & NS \\
\hline & $<0.02$ p.p.m. & $19(4 / 21)$ & $27.2(83 / 305)$ & \\
\hline \multirow[t]{2}{*}{ Total VSCs } & $\geqslant 0.25$ p.p.m. & $90.5(19 / 21)$ & $76.1(232 / 305)$ & NS \\
\hline & $<0.25$ p.p.m. & $9.5(2 / 21)$ & $23.9(73 / 305)$ & \\
\hline \multirow[t]{2}{*}{ OLT score } & $\geqslant 3$ & $57.1(12 / 21)$ & $43.3(132 / 305)$ & NS \\
\hline & $<3$ & $42.9(9 / 21)$ & $56.7(173 / 305)$ & \\
\hline \multicolumn{5}{|l|}{ Clinical parameter } \\
\hline \multirow[t]{2}{*}{ Tongue-coating score } & $\geqslant 3$ & $4.8(1 / 21)$ & $18.7(57 / 305)$ & NS \\
\hline & $<3$ & $95.2(20 / 21)$ & $81.3(248 / 305)$ & \\
\hline \multirow[t]{2}{*}{ Caries } & Presence & $19.0(4 / 21)$ & $22.0(67 / 305)$ & NS \\
\hline & Absence & $81.0(17 / 21)$ & $78.0(238 / 305)$ & \\
\hline \multirow[t]{2}{*}{ No-good margin } & Presence & $14.3(3 / 21)$ & $7.5(23 / 305)$ & NS \\
\hline & Absence & $85.7(18 / 21)$ & $92.5(282 / 305)$ & \\
\hline \multirow[t]{2}{*}{ Tooth mobility } & Presence & $38.1(8 / 21)$ & $18.0(55 / 305)$ & $<0.05$ \\
\hline & Absence & $61.9(13 / 21)$ & $82.0(250 / 305)$ & \\
\hline \multirow[t]{4}{*}{ PPD } & $\geqslant 5 \mathrm{~mm}$ & $76.2(16 / 21)$ & $37.0(113 / 305)$ & $<0.01$ \\
\hline & $<5 \mathrm{~mm}$ & $23.8(5 / 21)$ & $63.0(192 / 305)$ & \\
\hline & $\geqslant 6 \mathrm{~mm}$ & $57.1(12 / 21)$ & $29.8(91 / 305)$ & $<0.01$ \\
\hline & $<6 \mathrm{~mm}$ & $42.9(9 / 21)$ & $70.2(214 / 305)$ & \\
\hline \multirow[t]{2}{*}{ Occult blood in the saliva } & Presence & $66.7(14 / 21)$ & $36.7(112 / 305)$ & $<0.01$ \\
\hline & Absence & $33.3(7 / 21)$ & $63.3(193 / 305)$ & \\
\hline \multicolumn{5}{|l|}{ Periodontal bacteria } \\
\hline \multirow[t]{2}{*}{ Porphyromonas gingivalis } & Presence & $76.2(16 / 21)$ & $36.7(112 / 305)$ & $<0.01$ \\
\hline & Absence & $23.8(5 / 21)$ & $63.3(193 / 305)$ & \\
\hline \multirow[t]{2}{*}{ Treponema denticola } & Presence & $85.7(18 / 21)$ & $54.4(166 / 305)$ & $<0.01$ \\
\hline & Absence & $14.3(3 / 21)$ & $45.6(139 / 305)$ & \\
\hline \multirow[t]{2}{*}{ Prevotella intermedia } & Presence & $66.7(14 / 21)$ & $26.2(80 / 305)$ & $<0.01$ \\
\hline & Absence & $33.3(7 / 21)$ & $73.8(225 / 305)$ & \\
\hline
\end{tabular}

${ }^{\star} \chi^{2}$ test. NS, Not significant. 
in the saliva were significantly greater in the $H$. pyloripositive subjects. The prevalence of Porphyromonas gingivalis, Treponema denticola and Prevotella intermedia in the $H$. pylori-positive subjects was $76.2,85.7$ and $66.7 \%$, respectively. These periodontopathic bacteria were detected more frequently with $H$. pylori $(P<0.01)$. Ishihara et al. (1997) reported that Porphyromonas gingivalis and $F$. nucleatum selectively co-aggregate with $H$. pylori. Various oral bacterial species, however, are able to inhibit the growth of $H$. pylori (Okuda et al., 2003). The fact that subjects with good oral hygiene harbour less $H$. pylori in their mouths can be explained by the inhibitory activity of early colonizers of dental biofilm, such as oral streptococci, against that species. Periodontopathic bacteria, including Porphyromonas gingivalis, Treponema denticola and Prevotella intermedia, produce $\mathrm{H}_{2} \mathrm{~S}$ from L-cysteine and $\mathrm{CH}_{3} \mathrm{SH}$ from L-methionine (Fukamachi et al., 2005; Tonzetich \& McBride, 1981). H. pylori is capable of producing $\mathrm{H}_{2} \mathrm{~S}$ and $\mathrm{CH}_{3} \mathrm{SH}$, although the production of these compounds is complicated and strain specific (Lee et al., 2006).

\section{Prevalence of oral $\boldsymbol{H}$. pylori and oral malodour in periodontal subjects}

Subjects with a tongue-coating score of $\geqslant 3$ had more actual malodour ( $\geqslant 0.25$ p.p.m. total VSCs) than the subjects with a tongue-coating score of $\leqslant 2(P<0.01)$, but no correlation was observed between carriage of $H$. pylori and tongue-coating score. To evaluate the relationship between $H$. pylori and oral malodour according to periodontal status, those subjects with a PPD of $\geqslant 5 \mathrm{~mm}$ and a tongue coating score of $\leqslant 2(n=102)$ were selected (Table 4). Both the concentration of VSCs and the OLT scores were higher in the $H$. pylori-positive subjects, but the differences between the $H$. pylori-positive and -negative

Table 4. Oral malodour parameters in the $H$. pylori-positive and -negative subjects with a PPD of $\geqslant 5 \mathrm{~mm}$ and a tongue coating score of $\leqslant 2$

\begin{tabular}{|c|c|c|c|c|}
\hline Parameter & & H. pylori-positive $(n=16)$ & H. pylori-negative $(n=86)$ & $P$ value \\
\hline Number of teeth & & $26.4 \pm 2.6$ & $25.8 \pm 4.7$ & NS \\
\hline \multicolumn{5}{|l|}{ Oral malodour levels } \\
\hline \multirow[t]{2}{*}{$\mathrm{H}_{2} \mathrm{~S}$} & $\geqslant 0.15$ p.p.m. & $100.0(16 / 16)$ & $82.6(71 / 86)$ & NS \\
\hline & $<0.15$ p.p.m. & $0(0 / 16)$ & $17.4(15 / 86)$ & \\
\hline $\mathrm{CH}_{3} \mathrm{SH}$ & $<0.05$ p.p.m. & $0(0 / 16)$ & $7.0(6 / 86)$ & \\
\hline \multirow[t]{2}{*}{$\mathrm{CH}_{3} \mathrm{SCH}_{3}$} & $\geqslant 0.02$ p.p.m. & $93.8(15 / 16)$ & $90.7(78 / 86)$ & NS \\
\hline & $<0.02$ p.p.m. & $6.25(1 / 16)$ & $9.3(8 / 86)$ & \\
\hline \multirow[t]{2}{*}{ Total VSCs } & $\geqslant 0.25$ p.p.m. & $93.8(15 / 16)$ & $88.4(76 / 86)$ & NS \\
\hline & $<0.25$ p.p.m. & $6.25(1 / 16)$ & $11.6(10 / 86)$ & \\
\hline OLT score & $\geqslant 3$ & $68.8(11 / 16)$ & $61.6(53 / 86)$ & NS \\
\hline \multirow[t]{2}{*}{ No-good margin } & Presence & $12.5(2 / 16)$ & $12.8(11 / 86)$ & NS \\
\hline & Absence & $87.5(14 / 16)$ & $87.2(75 / 86)$ & \\
\hline \multirow[t]{2}{*}{ Tooth mobility } & Presence & $43.8(7 / 16)$ & $36.0(31 / 86)$ & NS \\
\hline & Absence & $56.2(9 / 16)$ & $64.0(55 / 86)$ & \\
\hline \multirow[t]{2}{*}{ Occult blood in the saliva } & Presence & $87.5(14 / 16)$ & $50.0(43 / 86)$ & $<0.01 \dagger$ \\
\hline & Absence & $12.5(2 / 16)$ & $50.0(43 / 86)$ & \\
\hline \multicolumn{5}{|l|}{ Periodontal bacteria } \\
\hline \multirow[t]{2}{*}{ Porphyromonas gingivalis } & Presence & $81.2(13 / 16)$ & $67.4(58 / 86)$ & NS \\
\hline & Absence & $18.8(3 / 16)$ & $32.6(28 / 86)$ & \\
\hline \multirow[t]{2}{*}{ Treponema denticola } & Presence & $87.5(14 / 16)$ & $69.8(60 / 86)$ & NS \\
\hline & Absence & $12.5(2 / 16)$ & $30.2(26 / 86)$ & \\
\hline
\end{tabular}

NS, Not significant.

${ }^{\star}$ Significant difference between the $H$. pylori-positive and -negative subjects at $P<0.05$ (unpaired $t$-test).

$\dagger$ Significant difference between the $H$. pylori-positive and -negative subjects at $P<0.01$ ( $\chi^{2}$ test).

$\ddagger$ Significant difference between the $H$. pylori-positive and -negative subjects at $P<0.05$ ( $\chi^{2}$ test). 
subjects were not significant. In the patients with periodontitis, elevated numbers of other VSC-producing bacteria were present in the oral cavity (Tanaka et al., 2004). Further detailed analysis should be performed to explore the relationship between the number of $H$. pylori present and halitosis levels. Note that the amount of occult blood in the saliva was greater in the $H$. pylori-positive subjects ( $P$ $<0.01)$. H. pylori has been suggested to have a special preference for the activated state of inflammation in periodontitis and several studies have reported that carriage of $H$. pylori may be associated with periodontal disease (Gebara et al., 2006; Okuda et al., 2003; Souto \& Colombo, 2008). Our results suggest that the presence of $H$. pylori in the oral cavity may be related to halitosis through periodontal pocketing and inflammation, rather than VSC-producing ability. The prevalence of Prevotella intermedia was higher in the $H$. pylori-positive subjects $(P$ $<0.05$ ), whilst the prevalence of Porphyromonas gingivalis and Treponema denticola was independent of the presence of $H$. pylori in those subjects with periodontal symptoms. Prevotella intermedia has been detected in various parts of the oral cavity, including periodontal pockets, tongue debris and supragingival plaque. Prevotella intermedia ATCC 25611, however, failed to co-aggregate with $H$. pylori in vitro (Ishihara et al., 1997), although the human oral cavity contains more than 500 bacterial species that interact with each other and with the tissues of their host (Kroes et al., 1999; Paster et al., 2001). The composition of these complex microbial communities varies in different ecological niches, such as the gingival crevice, tongue, buccal mucosa and saliva. Additional research is needed to confirm the local existence of these organisms.

\section{ACKNOWLEDGEMENTS}

This study was supported by Grants-in-Aid for Scientific Research (C) 18592296 (to T.H.), 20592249 (to M.Y.) and 20592444 (to T.N.); a Grant-in-Aid for Young Scientists (B) 19791645 (to N.S.); and Grants-in-Aid for Frontier Research from the Ministry of Education, Culture, Sports, Science and Technology, Japan.

\section{REFERENCES}

Adler, I., Denninghoff, V. C., Alvarez, M. I., Avagnina, A., Yoshida, R. \& Elsner, B. (2005). Helicobacter pylori associated with glossitis and halitosis. Helicobacter 10, 312-317.

Anand, P. S., Nandakumar, K. \& Shenoy, K. T. (2006). Are dental plaque, poor oral hygiene, and periodontal disease associated with Helicobacter pylori infection? J Periodontol 77, 692-698.

Ashimoto, A., Chen, C., Bakker, I. \& Slots, J. (1996). Polymerase chain reaction detection of 8 putative periodontal pathogens in subgingival plaque of gingivitis and advanced periodontitis lesions. Oral Microbiol Immunol 11, 266-273.

Covacci, A., Telford, J. L., Del Gludice, G., Parsonnet, J. \& Rappuoli, R. (1999). Helicobacter pylori virulence and genetic geography. Science 284, 1328-1333.

Czesnikiewicz-Guzik, M., Karczewska, E., Bielanski, W., Guzik, T. J., Kapera, P., Targosz, A., Konturek, S. J. \& Loster, B. (2004).
Association of the presence of Helicobacter pylori in the oral cavity and in the stomach. J Physiol Pharmacol 55 (Suppl. 2), 105-115.

Delanghe, G., Ghyselen, J., van Steenberghe, D. \& Feenstra, L. (1997). Multidisciplinary breath-odour clinic. Lancet 350, 187.

Dunn, B. E., Roop, R. M., II, Sung, C. C., Sharma, S. A., Perez-Perez, G. I. \& Blaser, M. J. (1992). Identification and purification of a cpn60 heat shock protein homolog from Helicobacter pylori. Infect Immun 60, 1946-1951.

Fujisawa, T., Kumagai, T., Akamatsu, T., Kiyosawa, K. \& Matsunaga, Y. (1999). Changes in seroepidemiological pattern of Helicobacter pylori and hepatitis A virus over the last 20 years in Japan. Am J Gastroenterol 94, 2094-2099.

Fukamachi, H., Nakano, Y., Okano, S., Shibata, Y., Abiko, Y. \& Yamashita, Y. (2005). High production of methyl mercaptan by Lmethionine- $\alpha$-deamino- $\gamma$-mercaptomethane lyase from Treponema denticola. Biochem Biophys Res Commun 331, 127-131.

Gebara, E. C., Faria, C. M., Pannuti, C., Chehter, L., Mayer, M. P. \& Lima, L. A. (2006). Persistence of Helicobacter pylori in the oral cavity after systemic eradication therapy. J Clin Periodontol 33, 329-333.

Goldberg, S., Kozlovsky, A., Gordon, D., Gelernter, I., Sintov, A. \& Rosenberg, M. (1994). Cadaverine as a putative component of oral malodor. J Dent Res 73, 1168-1172.

Ishihara, K., Miura, T., Kimizuka, R., Ebihara, Y., Mizuno, Y. \& Okuda, K. (1997). Oral bacteria inhibit Helicobacter pylori growth. FEMS Microbiol Lett 152, 355-361.

Kleinberg, I. \& Westbay, G. (1990). Oral malodor. Crit Rev Oral Biol Med 1, 247-259.

Kostelc, J. G., Zelson, P. R., Preti, G. \& Tonzetich, J. (1981). Quantitative differences in volatiles from healthy mouths and mouths with periodontitis. Clin Chem 27, 842-845.

Kroes, I., Lepp, P. W. \& Relman, D. A. (1999). Bacterial diversity within the human subgingival crevice. Proc Natl Acad Sci U S A 96, 14547-14552.

Lee, H., Kho, H. S., Chung, J. W., Chung, S. C. \& Kim, Y. K. (2006). Volatile sulfur compounds produced by Helicobacter pylori. J Clin Gastroenterol 40, 421-426.

Lee, S. S., Zhang, W. \& Li, Y. (2007). Halitosis update: a review of causes, diagnoses, and treatments. J Calif Dent Assoc 35, 258-260, 262, 264-268.

Loster, B. W., Majewski, S. W., Czesnikiewicz-Guzik, M., Bielanski, W., Pierzchalski, P. \& Konturek, S. J. (2006). The relationship between the presence of Helicobacter pylori in the oral cavity and gastric in the stomach. J Physiol Pharmacol 57 (Suppl. 3), 91-100.

Malaty, H. M., Tanaka, E., Kumagai, T., Ota, H., Kiyosawa, K., Graham, D. Y. \& Katsuyama, T. (2003). Seroepidemiology of Helicobacter pylori and hepatitis A virus and the mode of transmission of infection: a 9year cohort study in rural Japan. Clin Infect Dis 37, 1067-1072.

Miyazaki, H., Arao, M., Okamura, K., Kawaguchi, Y., Toyofuku, A., Hoshi, K. \& Yaegaki, K. (1999). Tentative classification for halitosis patients and its treatment needs. Niigata Dent J 32, 11-15.

Nyan, D. C., Welch, A. R., Dubois, A. \& Coleman, W. G., Jr (2004). Development of a noninvasive method for detecting and monitoring the time course of Helicobacter pylori infection. Infect Immun 72, $5358-5364$.

Oho, T., Yoshida, Y., Shimazaki, Y. \& Yamashita, Y. (2001). Characteristics of patients complaining of halitosis and the usefulness of gas chromatography for diagnosing halitosis. Oral Surg Oral Med Oral Pathol Oral Radiol Endod 91, 531-534.

Okuda, K., Kimizuka, R., Katakura, A., Nakagawa, T. \& Ishihara, K. (2003). Ecological and immunopathological implications of oral bacteria in Helicobacter pylori-infected disease. J Periodontol 74, 123-128. 
Olivier, B. J., Bond, R. P., van Zyl, W. B., Delport, M., Slavik, T., Ziady, C., Terhaar Sive Droste, J. S., Lastovica, A. \& van der Merwe, S. W. (2006). Absence of Helicobacter pylori within the oral cavities of members of a healthy South African community. J Clin Microbiol 44, 635-636.

Parsonnet, J., Vandersteen, D., Goates, J., Sibley, R. K., Pritikin, J. \& Chang, Y. (1991). Helicobacter pylori infection in intestinal- and diffuse-type gastric adenocarcinomas. J Natl Cancer Inst 83, 640-643.

Parsonnet, J., Blaser, M. J., Perez-Perez, G. I., Hargrett-Bean, N. \& Tauxe, R. V. (1992). Symptoms and risk factors of Helicobacter pylori infection in a cohort of epidemiologists. Gastroenterology 102, 41-46.

Paster, B. J., Boches, S. K., Galvin, J. L., Ericson, R. E., Lau, C. N., Levanos, V. A., Sahasrabudhe, A. \& Dewhirst, F. E. (2001). Bacterial diversity in human subgingival plaque. J Bacteriol 183, 3770-3783.

Rosenberg, M., Kulkarni, G. V., Bosy, A. \& McCulloch, C. A. (1991). Reproducibility and sensitivity of oral malodor measurements with a portable sulphide monitor. J Dent Res 70, 1436-1440.

Scully, C., Porter, S. \& Greenman, J. (1994). What to do about halitosis. BMJ 308, 217-218.

Shimada, T., Ogura, K., Ota, S., Terano, A., Takahashi, M., Hamada, E., Omata, M., Sumino, S. \& Sassa, R. (1994). Identification of Helicobacter pylori in gastric specimens, gastric juice, saliva and faeces of Japanese patients. Lancet 343, 1636-1637.

Souto, R. \& Colombo, A. P. (2008). Detection of Helicobacter pylori by polymerase chain reaction in the subgingival biofilm and saliva of non-dyspeptic periodontal patients. J Periodontol 79, 97-103.

Suzuki, N., Yoneda, M., Naito, T., Iwamoto, T. \& Hirofuji, T. (2008). Relationship between halitosis and psychologic status. Oral Surg Oral Med Oral Pathol Oral Radiol Endod (in press).

Tanaka, M., Yamamoto, Y., Kuboniwa, M., Nonaka, A., Nishida, N., Maeda, K., Kataoka, K., Nagata, H. \& Shizukuishi, S. (2004).
Contribution of periodontal pathogens on tongue dorsa analyzed with real-time PCR to oral malodor. Microbes Infect 6, 1078-1083.

Tangerman, A. \& Winkel, E. G. (2007). Intra- and extra-oral halitosis: finding of a new form of extra-oral blood-borne halitosis caused by dimethyl sulphide. J Clin Periodontol 34, 748-755.

Taylor, D. N. \& Blaser, M. J. (1991). The epidemiology of Helicobacter pylori infection. Epidemiol Rev 13, 42-59.

Tonzetich, J. (1977). Production and origin of oral malodor: a review of mechanisms and methods of analysis. J Periodontol 48, 13-20.

Tonzetich, J. \& McBride, B. C. (1981). Characterization of volatile sulphur production by pathogenic and non-pathogenic strains of oral Bacteroides. Arch Oral Biol 26, 963-969.

Tonzetich, J. \& Ng, S. K. (1976). Reduction of malodor by oral cleansing procedures. Oral Surg Oral Med Oral Pathol 42, 172-181.

Tydd, T. F. \& Dyer, N. H. (1974). Pyloric stenosis presenting with halitosis. BMJ 3, 321.

Warren, J. R. \& Marshall, B. J. (1983). Unidentified curved bacilli on gastric epithelium in active chronic gastritis. Lancet 321, 1273-1275.

Yaegaki, K. \& Coil, J. M. (2000). Examination, classification and treatment of halitosis; clinical perspectives. J Can Dent Assoc 66, 257-261.

Yaegaki, K. \& Sanada, K. (1992). Biochemical and clinical factors influencing oral malodor in periodontal patients. J Periodontol 63, 783-789.

Yoneda, M., Naito, T., Suzuki, N., Yoshikane, T. \& Hirofuji, T. (2006). Oral malodor associated with internal resorption. J Oral Sci 48, 89-92.

Yoshida, Y., Suzuki, N., Nakano, Y., Shibuya, K., Ogawa, Y. \& Koga, T. (2003). Distribution of Actinobacillus actinomycetemcomitans serotypes and Porphyromonas gingivalis in Japanese adults. Oral Microbiol Immunol 18, 135-139. 